\title{
CONSERVATION STATUS AND THREATS TO ENDEMIC PLANT SPECIES OF GRIQUALAND WEST OF SOUTH AFRICA
}

\author{
Samuel Oloruntoba BAMIGBOYE ${ }^{1}$ \\ ${ }^{1}$ Botany Department, School of Mathematical and Natural Sciences, University of Venda, \\ Thohoyandou 0950 - South Africa \\ E-mail: reachtoba@gmail.com
}

\begin{abstract}
Endemic species are important to biodiversity of any region they are situated. They are to be protected from over exploitation and population decline. This study evaluated the conservation status and threats to endemic plant species of Griqualand West in South Africa. The SANBI (South African National Biodiversity Institute) Red List data base was used in determining the conservation status and threats to these endemic species. The result of this study showed that all the endemic species of Griqualand West of South Africa are of conservation concern meaning they need to be given attention in terms of conservation. Also human induced threats were discovered in this study. This study thereby recommend that conservation priority should be given to the endemic species of this region that are of conservation concern, and also efforts should be made to control the human induced threats identified in this study.
\end{abstract}

Keywords: biodiversity loss, conservation, extinction risk, species endemism, threats.

\section{Introduction}

Many species are going extinct at an unprecedented rate with the current extinction crisis seen as the sixth mass extinction the world has ever witnessed [DANA \& al. 2012]. The effect of these biodiversity loss is resulting into great loss of ecosystem services [KHAN $\&$ al. 2013; TALI \& al. 2015]. Factors causing species extinction includes human population growth, anthropogenic activities, climate change, invasive species and unsustainable resource utilization [HOFFMANN \& al. 2010].

Endemic species are critically important to biodiversity and their loss translates into significant biodiversity loss [ANDERSON, 2002]. These species are exploited for several human uses and some of them that are protected by authorities are illegally collected to meet certain human demands [WILLIAMS \& al. 2013; BAMIGBOYE \& al. 2017]. Several regions of plant endemism have been identified in South Africa and some of these regions are being faced with threats to these species hence increasing their risk of extinction [van WYK, 1996; SIEBERT \& al. 2002; BIGGS \& al. 2008; CLARK \& al. 2009; WILLIAMSON \& BALKWIL, 2015; HAHN, 2017; MORASWI \& al. 2019].

This study evaluated the conservation status and threats to the endemic plant species of Griqualand West in South Africa, a region where the endemic species list have recently been updated. 


\section{Materials and methods}

Griqualand West is primarily situated in the Northern Cape Province but extend to the Northwest Province of South Africa with a coverage of $40,000 \mathrm{~km}^{2}$ [COON \& HUNT, 1965]. It is a semi-arid region with average rainfall of 262 to $411 \mathrm{~m}$ annually [FRISBY \& al. 2019]. The mean annual temperature of this region is between 17 to $18{ }^{\circ} \mathrm{C}$ [MUCINA \& RUTHERFORD, 2006]. The vegetation type is savannah biome which is dominated by grasses and herbaceous ground layers [MUCINA \& RUTHERFORD, 2006].

The list of the 25 endemic plant species was gotten from FRISBY \& al. (2019). The Red List status of these species was gotten from SANBI Red List web page (http://redlist.sanbi.org/redcat.php) 2017 version. The threats for each of the species were also gotten from the SANBI Red List data base 2017 version. Percentages of different threat categories of SANBI Red List were calculated and the percentage of the species facing different kind of threats were also calculated.

\section{Results and discussion}

The result of the SANBI Red List categorical percentages of endemic plant species of Griqualand West of South Africa are as follows: $8 \%$ are Vulnerable, $8 \%$ are Near Threatened, $12 \%$ are Data Deficient Taxonomically Problematic, $4 \%$ are Rare, $4 \%$ are Critically Rare, $4 \%$ are not found on SANBI Red List and 60\% are of Least Concern. 36\% of all the endemic plant species of Griqualand West of South Africa are of conservation concern (Vulnerable, Near Threatened, Critically Rare, Rare, and Data Deficient Taxonomically Problematic). $12 \%$ are facing threats due to habitat degradation, while $4 \%$ facing threat due to pollution.

Irrespective of their conservation status, all endemic species that are within a very small geographic range in a country (e.g a state, a province, local districts or municipalities) deserves to be protected. But more attention should be drawn to threatened endemic species in terms conservation. It is recommended that high priority be given to species that are of conservation concern listed in this study (Table 1) in terms of conservation management. Endemic plant species that are Data Deficient Taxonomically Problematic could possibly be facing threats [MORASWI \& al. 2019]. Effort should be made to reassess the Data Deficient Taxonomically Problematic species found in this study (Table 1) to determine if some of them are threatened and also unravel factors that might be posing threats to them.

A species whose conservation status showed not threatened (Glossochilus burchellii Nees) in this study was discovered to be facing threat due to habitat degradation by reason of mining activities and overgrazing (Table 1). This showed that species that are not threatened in this study needs to still be further evaluated for threats and potential threats. The human induced threats already identified in this study (Table 1) should be controlled to reduce their impact on the endemic plant species of Griqualand West of South Africa.

New species description are sometimes setback in determining the overall conservation status of endemic species in a certain location [RIEMANN \& EZCURRA, 2005]. Because new species that are newly described may not have been assessed for conservation purpose and this results in shortfalls in quantifying overall conservation status of endemic species in certain regions [RIEMANN \& EZCURRA, 2005; MORASWI \& al. 2019]. A new species (Deverra rapaletsa Magee \& Zietsman) described by VAN MUNSTER \& al. (2019) found in this study is not yet on SANBI Red List and has not yet 
been assessed for conservation. It is recommended that this species should be assessed for conservation purpose to further contribute to the overall conservation of endemic plant species of Griqualand West of South Africa.

There is need to continuously evaluate endemic species to keep track their population trend and also determine how utilization of these species are posing threats to their existence [BAMIGBOYE \& al. 2017; MORASWI \& al. 2019]. This will enhance the monitoring of these species and also give direction to how initiatives can be generated to further protect and preserve these species. This means that studies on population size, structure and distribution of these species should be carried out continuously at least a decade interval on endemic plant species.

Table 1. List of plant species endemic to Griqualand West of South Africa, their SANBI Red List Status and their threats on SANBI Red List

\begin{tabular}{|c|c|c|c|}
\hline Family & Species & $\begin{array}{c}\text { SANBI } \\
\text { Red List Status }\end{array}$ & $\begin{array}{l}\text { Threats on SANBI } \\
\text { Red List }\end{array}$ \\
\hline Acanthaceae & Barleria media C. B. Clarke & Vulnerable & $\begin{array}{l}\text { Habitat degradation due to } \\
\text { overgrazing }\end{array}$ \\
\hline Acanthaceae & $\begin{array}{l}\text { Blepharis marginata (Nees) C. B. } \\
\text { Clarke }\end{array}$ & Least Concern & No threat found \\
\hline Acanthaceae & Glossochilus burchellii Nees & Least Concern & $\begin{array}{l}\text { Habitat degradation due to } \\
\text { mining and overgrazing }\end{array}$ \\
\hline Acanthaceae & Justicia puberula Immelman, FSA & Least Concern & No threat found \\
\hline Acanthaceae & $\begin{array}{l}\text { Justicia thymifolia (Nees) C. B. } \\
\text { Clarke }\end{array}$ & Least Concern & No threat found \\
\hline Aizoaceae & $\begin{array}{l}\text { Antimima lawsonii (L. Bolus) H. E. } \\
\text { K. Hartmann }\end{array}$ & Rare & No threat found \\
\hline Aizoaceae & Hereroa wilmaniae L. Bolus & $\begin{array}{l}\text { Data Deficient } \\
\text { Taxonomically } \\
\text { Problematic } \\
\end{array}$ & No threat found \\
\hline Aizoaceae & $\begin{array}{l}\text { Lithops aucampiae L. Bolus subsp. } \\
\text { euniceae (de Boer) D. T. Cole }\end{array}$ & Vulnerable & $\begin{array}{l}\text { Pollution which is affecting } \\
\text { both the habitat and the } \\
\text { species }\end{array}$ \\
\hline Aizoaceae & Lithops bromfieldii L. Bolus & Least Concern & No threat found \\
\hline Aizoaceae & $\begin{array}{l}\text { Lithops lesliei (N. E. Br.) N. E. Br. } \\
\text { subsp. burchellii D. T. Cole }\end{array}$ & Near Threatened & No threat found \\
\hline Aizoaceae & $\begin{array}{l}\text { Prepodesma orpenii (N. E. Br.) N. E. } \\
\text { Br. }\end{array}$ & Least Concern & No threat found \\
\hline Anarcadiaceae & Searsia tridactyla (Burch.) Moffett & Least Concern & No threat found \\
\hline Apiaceae & $\begin{array}{l}\text { Deverra rapaletsa } \text { Magee } \& \\
\text { Zietsman }\end{array}$ & Not on Red List & No threat found \\
\hline Asteraceae & Amphiglossa tecta (Brusse) Koek. & Critically Rare & No threat found \\
\hline Asteraceae & Cineraria exilis DC. & $\begin{array}{l}\text { Data Deficient } \\
\text { Taxonomically } \\
\text { Problematic }\end{array}$ & No threat found \\
\hline
\end{tabular}


CONSERVATION STATUS AND THREATS TO ENDEMIC PLANT SPECIES OF GRIQUALAND ...

\begin{tabular}{|c|c|c|c|}
\hline Asteraceae & Dicoma kurumanii S. Ortiz \& Netnou & Least Concern & No threat found \\
\hline Asteraceae & $\begin{array}{l}\text { Eriocephalus ericoides (L. f.) Druce } \\
\text { subsp. griquensis M. A. N. Müll. }\end{array}$ & Least Concern & No threat found \\
\hline Asteraceae & $\begin{array}{l}\text { Gnaphalium englerianum (O. } \\
\text { Hoffm.) Hilliard \& B. L. Burtt }\end{array}$ & Least Concern & No threat found \\
\hline Asteraceae & $\begin{array}{l}\text { Pentzia stellata (P. P. J. Herman) } \\
\text { Magee }\end{array}$ & Near Threatened & $\begin{array}{l}\text { Habitat degradation due to } \\
\text { trampling and overgrazing }\end{array}$ \\
\hline Asteraceae & Tarchonanthus obovatus DC. & Least Concern & No Threat found \\
\hline Celastraceae & Maytenus ilicina (Burch.) Loes. & Least Concern & No threat found \\
\hline Celastraceae & Putterlickia saxatilis (Burch.) Jordaan & Least Concern & No threat found \\
\hline Fabaceae & $\begin{array}{l}\text { Calobota cuspidosa (Burch.) Boatwr. } \\
\& \text { B.-E. Van Wyk }\end{array}$ & Least Concern & No threat found \\
\hline Poaceae & $\begin{array}{l}\text { Brachiaria dura Stapf. var. pilosa J. } \\
\text { G. Anderson }\end{array}$ & $\begin{array}{l}\text { Data Deficient } \\
\text { Taxonomically } \\
\text { Problematic } \\
\end{array}$ & No threat found \\
\hline Stilbaceae & Nuxia gracilis Engl. & Least Concern & No threat found \\
\hline
\end{tabular}

\section{Conclusions}

This study recommend protection of all the endemic plant species of Griqualand West of South Africa. But beyond protection, there is a need to come up with initiatives on how threats and potential threats to these species can be controlled. Further studies of recent population biology of these species is recommended to further unravel their risk of extinction and their persistence amidst ecological forces posing threats to their existence.

\section{Notes on contributors}

Samuel Oloruntoba BAMIGBOYE is a plant biologist with specialization in plant ecology and conservation biology. His research interest is studying patterns of extinction risk in African flora with special interest in endemic species. He is currently focusing on threatened species and endemic species in South Africa.

\section{References}

ANDERSON S. 2002. Identifying Important Plant Areas. Plantlife International, London.

BAMIGBOYE S. O., TSHISIKHAWE P. M. \& TAYLOR P. J. 2017. Detecting threat to Encephalartos transvenosus (Limpopo cycad) through indigenous knowledge in Limpopo province, South Africa. Indian Journal of Traditional Knowledge. 16(2): 251-255.

BIGGS R., SIMONS H., BAKKENES M., SCHOLES R. J., EICKHOUT B., VAN VUUREN D. \& ALKEMADE R. 2008. Scenarios of biodiversity loss in southern Africa in the $21^{\text {st }}$ century. Global Environmental Change. 18: 296-309. https://doi.org/10.1016/j.gloenvcha.2008.02.001

CLARK V. R., BARKER N. P. \& MUCINA L. 2009. The Sneeuberg: a new centre of floristic endemism on the Great Escarpment, South Africa. South African Journal of Botany. 75: 196-238. https://doi.org/10.1016/j.sajb.2008.10.010

COON C. S. \& HUNT E. E. 1965. The living races of man. Human Biology. 39: 330-333. 
DANA G. V., KAPUSCINSKI A. R. \& DONALDSON J. S. 2012. Integrating diverse scientific and practitioner knowledge in ecological risk analysis: A case study of biodiversity risk assessment in South Africa. Journal of Environmental Management. 98: 134-146. https://doi.org/10.1016/j.jenvman.2011.12.021

FRISBY A. W., SIEBERT S. J., STRUWIG M. \& CILLIERS D. P. 2019. Plant Endemism in Griqualand West of South Africa. South African Journal of Botany. 124: 127-137.

HAHN N. 2017. Endemic flora of the Soutpansberg, Blouberg and Makgabeng. South African Journal of Botany. 113: 324-336. https://doi.org/10.1016/j.sajb.2017.09.006

HOFFMANN M., HILTON-TAYLOR C., ANGULO A., BÖHM M., BROOKS T. M., BUTCHART S. H. M., CARPENTER K. E., CHANSON J., COLLEN B., COX N. A., DARWALL W. R. T., DULVY N. K., HARRISON L. R., KATARIYA V., POLLOCK C. M., QUADER S., RICHMAN N. I., RODRIGUES A. S. L., TOGNElli M. F., VIE J. C., AGUiAR J. M., ALlEN D. J., ALLEN G. R. \& AMORI G. 2010. The impact of conservation on the status of the world's vertebrates. Science New Series. 330: 1503-1509. https://doi.org/10.1126/science.1194442

KHAN S. M., PAGE S. E., AHMAD H. \& HARPER D. M. 2013. Sustainable utilization and conservation of plant biodiversity in montane ecosystems: the western Himalayas as a case study: Plant biodiversity conservation in montane ecosystems. Annals of Botany. 112: 479-501. https://doi.org/10.1093/aob/mct125

MORASWI I., BAMIGBOYE S. O. \& TSHISIKHAWE M. P. 2019. Conservation status and threats to vascular plant species endemic to Soutpansberg Mountain in Limpopo Province, South Africa. International Journal of Plant Biology. 10: 7978. https://doi.org/10.4081/pb.2019.7978: 14-16.

MUCINA L. \& RUTHERFORD. M. C. 2006. The vegetation of South Africa, Lesotho and Swaziland. Strelitzia 19. South African National Biodiversity Institute, Pretoria.

RIEMANN H. \& EZCURRA E. 2005. Plant Endemism and natural protected area in the peninsula of Baja California, Mexico. Biological Conservation. 122: 141-50. https://doi.org/10.1016/j.biocon.2004.07.008

SIEBERT S. J., VAN WYK A. E. \& BREDENKAMP G. J. 2002. The physical environment and major vegetation types of Sekhukhuneland, South Africa. South African Journal of Botany. 68: 127-142. https://doi.org/10.1016/S0254-6299(15)30412-9

SOUTH AFRICAN NATIONAL BIODIVERSITY INSTITUTE (SANBI) Red List 2017 version. http://redlist.sanbi.org/redcat.php

TALI B. A., GANIE A. H., NAWCHOO I. A., WANI A. A. \& RESHI A. Z. 2015. Assessment of threat status of selected endemic medicinal plants using IUCN regional guidelines: A case study from Kashmir Himalaya. Journal for Nature Conservation. 23: 80-89.

VAN MUNSTER S., MAGEE A. R. \& ZIETSMAN P. Z. 2019. Deverra rapaletsa (Apiaceae), a new limestone endemic species from the Ghaap Plateau, Northern Cape, South Africa. South African Journal of Botany. 121: $431-434$.

VAN WYK A. E. 1996. Biodiversity of the Maputuland Centre. In: VAN DER MAESEN L. J. G., VAN DER BURGT X. M., VAN MEDEBACH DE ROOY J. M. (Eds.). The Biodiversity of African Plants. Kluwer Academic Publishers, Dordrecht, pp. 198-207.

WILLIAMS V. L., VICTOR J. E. \& CROUCH N. R. 2013. Red listed medicinal plants of South Africa: status, trend and assessment challenges. South African Journal of Botany. 86: 23-35. https://doi.org/10.1016/j.sajb.2013.01.006

WILLIAMSON S. D. \& BALKWILL K. 2015. Plant census and floristic analysis of selected serpentine outcrops of the Barberton Greenstone Belt, Mpumalanga, South Africa. South African of Journal Botany. 97: 133142. https://doi.org/10.1016/j.sajb.2014.12.004

How to cite this article:

BAMIGBOYE S. O. 2019. Conservation status and threats to endemic plant species of Griqualand West of South Africa. J. Plant Develop. 26: 117-121. https://doi.org/10.33628/jpd.2019.26.1.117 